\title{
The Effect of Mingle Model to Improve Reading Skills for Students with Dyslexia in Primary School
}

\author{
Irdamurni, Kasiyati, Zulmiyetri, Johandri Taufan \\ Universitas Negeri Padang, Indonesia \\ Email: irdamurni@fip.unp.ac.id
}

\begin{abstract}
Dyslexia is a cognitive process failure in acquiring information when reading. Children normally have been able to read at the age of 6 or 7 while children with dyslexia might still struggle with reading even when they reach 12 . This research was conducted by mingle model in order to improve reading skills for dyslexic students in primary grades. The subjects selected were 23 students with dyslexia in primary grades. The research used purposive sampling and the data collected by conducting the reading test to the students. Descriptive analysis was performed as the method and intervention technique employed was mingle model. The research was carried out continually in seven days. The assessment presented in pre-intervention and post-intervention ( $47 \%$ and $71 \%$ respectively) showed improvement in the average value in reading skills. Findings showed that mingle model had significantly improved dyslexic students' reading skills in primary grades.
\end{abstract}

Keywords: mingle model, reading, children with dyslexia

\section{INTRODUCTION}

Dyslexia is specific language-based disorder characterized by the inability in expressing and acquiring information in oral or written and possibly emerged in reading, speaking, listening and writing. Dyslexia is a common disorder (Watson \& Williams, 1995) and a new study from (Bhatnagar et al., 2000; Leisman, 2002; Simos et al., 2002) caused by cognitive process failure in acquiring information when reading a book or passage. Children's ability to read normally have begun at the age of 6 or 7 , while children with dyslexia have not been able to read even when they are adults. Dyslexia is manifested by the reading difficulty in children and adults at the age when they are supposed to show skills and motivation in reading correctly and fluently. In some cases, for example, the word 'pulang' is spelled as 'puang' or 'mandi' is spelled as 'pagi'.

Dyslexia in pre-school children is diagnosed by the inability to recognize the sound from a word (difficulty in identifying rhyming words, similar words, and letters) for instance, the word ' $k a k a k$ ' is spelled as 'gagak'. A child with a family history in language impairment would be at risk for dyslexia. Students with dyslexia typically have the problem in reading such as the word 'ayam' read reversely as 'maya' which parents and teachers are sometimes unaware of the symptom. Children with dyslexia suffered from reading regression even when they reach 12 and this symptom can be detected when children enrolled in primary school.

The prevalent number of children with learning disability according to several kinds of literature are ranged from $1 \%$ to $30 \%$ in the classroom (Lerner, 1981; Lovit, 1989).In Indonesia, the number is estimated even bigger. The research from Balitbang Dikbud in four provinces found that $10 \%$ of children suffered from dysgraphia, $9 \%$ suffered from dyslexia and more than $8 \%$ suffered from dyscalculia. The research also found that $22 \%$ of children with learning difficulty have high intelligence. Meanwhile, Out of $15 \%$ of children with dyslexia in the world, $4 \%$ of them have a severe disorder and $10 \%$ have a minor disorder. As explained above, the learning disability is not associated with low intelligence and caused by other influential factors. Findings from the research conducted by Irdamurni and Noviana, 2013 in Kuranji, Pauh subdistrict in Padang, showed the prevalence rate of $41,47 \%$ which indicated many children in Padang have the learning disability.

Research showed that dyslexia is caused by biological factors and resulted in frustration and despondency which later leads into a poor social relationship and affects individual's behavior caused by anxiety, anger, inferiority and depression (dyslexia International Association). Chall cited by Mercer \& Mercer (1979) found after the research he conducted in 1967 that approach emphasized in symbols recognition is more efficient than words or sentence recognition. Kirk \& Gallagher (1962) provide a model in the reading method, which consists of 3 steps; (1) reading in general, (2) reading in details, (3) reding without details awareness. Moreover, Mercer \& Mercer (1979), Lerner, (1988) and Zipprich, Mary Ann, Grace, Marscha, Crote-Gracia, and Stephane cited in Martini (2009) stated that there are two methods of teaching 
reading namely reading method for pupils and reading method for pupils with learning disability. The method used in teaching reading for normal pupils are (1) conscious reading, (2) phonics, (3) linguistics, (4) SAS, (5) alphabetic, and (5) language experience. On the other hand, the method for dyslexic pupils according to Martini (2009) are (a) Final method, (b) Gillingham method, and (c) Glass Analysis method. And one of the techniques used to overcome learning disability for dyslexic pupils is Mingle model.

Mingle according to Oxford dictionary means to mix. The word 'mingle' when associated with human daily activity means to mix up socially. In the learning process, 'mingle' is defined as students' collective action to achieve a social purpose. 'Mingle' is first coined by Pollard \& Hess (1997) in their book Zero Prep: Ready to go Activities for Teachers. The model was later pinned into the method for children with dyslexia. Pollard \& Hess (1997) pointed out that Mingle model is a game model with certain steps in reading and speaking skills. According to Hurlock (2004), students in first grade are in a phase to play. Walker \& Norman (2006) similarly argued that teaching reading skills for primary students need a particular strategy which fitted in children's realm where the situation is made fun. The context is determined in a particular situation where students move around while reading.

Furthermore, Pollard \& Hess (1997) explained that this model could be applied to the questionnaire and implemented into matching activities and role play. This model is relevant to the characteristics of primary school students and makes them become active (Bond, 1979). Results of the research found that game-based learning improves motivation, confidence, speak fluency and interaction. This model is established for dyslexic students whose characteristics according to Mercer,\& Mercer (1979), Yusuf et al., (2018) showed subsequent routines in reading and writing; turning their head left and right, frowning, becoming anxious, sounding in high tone, biting lips, and sometimes refusing and crying when the teacher asked to read. Therefore, this research aims to analyze the influence of mingle model to improve reading skills for dyslexic students in inclusive primary school.

\section{METHOD}

This research is a descriptive analysis which according to Scarborough et al. (2009) provides a detail description of a situation, social setting or a relationship. The researcher begins by identifying the subjects and conducting the research with accurate analysis. The findings of the analysis are the detailed description of the subjects.
Subjects selected in this research were students in second and third grade whose reading proficiency is lacking compared to their peers. Lower grades are selected based on the findings from research by Anastaha et al. (2018) which showed many dyslexic children located in Kuranji, Padang and also a report from National Department of Education in 2004 about elementary reading for first graders. Besides, students are expected to transform letters and symbols into sound in the early years of primary school in order to comprehend the meaning of each word and sentence. The research sampling used purposive sampling which the subjects selected after certain characteristics and consideration.

Subjects selected based on screening identification of dyslexic students in the lower grade of primary school. The format identification is given to dyslexic students through teacher's assistance. This contains introducing vowel and consonant letters, connecting consonant and vowel letters into one syllable and combining them into word and simple sentence. Followed by the identification, out of 15 first graders who have reading difficulty, 10 found to be matched with dyslexia characteristics.

The research was performed by examining students' reading ability before and after the intervention. Prior to intervention, the test was conducted with letter recognition, reading syllable and reading words and simple sentences. The aspect assessed from this session is correct words recognition. The component of words recognition was measured by the amount of percentage of the words spelled in the correct structure using Argyle's Miscue Reading Analysis. Thereafter, the intervention was given in seven meetings using mingle model. Then, the data were analyzed by comparing the transformation from pre-intervention to post-intervention using a qualitative and narrative description of the subjects.

\section{FINDINGS AND DISCUSSION}

\section{Findings}

Findings showed that the screening of 10 students prior to intervention obtained the percentile rate of 69.02 and after seven days of intervention with mingle model, the value obtained was 71.10 , which confirmed to increased by 2.08 . The ability analysis of screening dyslexic students prior to intervention and after the intervention is explained as followed (students represented by code). (1) NS was able to recognize vowels and consonants but read in reverses such as the word 'lelap' spelled as 'lalap', linu spelled as 'lena' and 'lalu' spelled as 'lula'. After given the intervention, NS did not read in reverse when encountered two-syllables 
words but still was having trouble with three-syllable words. (2) TAF understood vowels and consonants and was able to connect syllable into word but read in reverses, such as 'ibu' spelled as ' $u b i$ ', 'nana' spelled as 'mama' and 'rawa' spelled as 'sama'. After given the intervention, TAF was able to read three-word sentence correctly. (3) SKW had reading regression before the intervention, such as the word ' $i b u$ ' spelled as 'idu', was unable to sound out letters from the word 'mama' and 'papa' and unable to spell his own name. After the intervention, SKW was able to sound out the given words and read two-syllable words even though was still troubled with three-syllable words. (4) RF had not yet understood about vowels and consonants. 'Bola' spelled as 'bela', 'ibu' spelled as 'idu'. After the intervention, RF understood vowels and consonants and was able to read two-syllable words. (5) PF word, had not yet understood about vowels and consonants, spelled the word 'ibu' as 'idu', read backward, was unable to recognize left from right and front from back. After the intervention, PF improved in reading even though was still troubled with reading syllable. (6) FD was unable to recognize letters and read syllable and words. After the intervention, FD understood about vowels and consonants while was still having a problem with reading syllable. (7) NL was unable to sound out his name and the word 'mama' and 'papa'. After the intervention, NL was able to sound out the words, but still read in reverse. (8) SK understood vowels and consonants but unable to read, spelled the word 'bola' as 'belo' and 'pola' as 'piko'. After the intervention, SK was able to read two-syllable words. (9) KR understood vowels and consonants but was unable to connect them and read words. 'Mama' spelled as 'meme' and 'papa' spelled as 'pepe'. After the intervention, KR had able to read two-syllable words. (10) ZH understood vowels and consonants but was unable to read the words 'duku', 'linu', 'lelap'. The word 'Juni' spelled as 'jana' and 'jari' spelled as 'jara'. After the intervention, $\mathrm{ZH}$ was able to sound out letters from his name and given words even though was still reading backward.

Findings showed that the students obtained 30 as lowest score and 70 as the highest score in the pretest. Meanwhile, the students scored 60 the lowest and 82 the highest in post-test. This confirmed a significant improvement in their reading skills. At the same time, the subjects' reading skills remain under category frustration reading, which means the percentage is below 90, as many subjects are unable to connect syllables into word. The improvement may not very high, nonetheless, the result is positive as the data analysis found that mingle model is proved to be influential to improve reading skills of dyslexic students in the primary grade.

\section{Discussion}

Mingle model provides an opportunity to develop reading skills for children with dyslexia. Teachers can observe the students reading skills including; vowels and consonants understanding, syllables, words and simple sentences. This model is expected to introduce a new concept of learning which students learn to read while playing with peers and teachers. This condition builds an enjoyable situation for students when learning vowels and consonants and combining them with the tool such as letter cards. The students also learn to sound out the vowels and consonants, hence they are able to assimilate the information into existing schemata. Soon, they learn to combine vowels and consonants and produce them into different sounds and accommodate the scheme.

This accommodation represents the students' ability to do little changes towards their vision of realm. This model also increases children's enjoyment in reading because mingle is a part of playing in learning which is relevant for primary students' characteristics and activates them (Bond, 1979).

Findings of the research showed that game-based learning method improves motivation, confidence, speaking fluency and interaction. Mingle model is found to be beneficial in learning preparation of dyslexic students' reading skills. Thus, the students enjoy to learn and the teachers have greater concentration and focus in teaching, as well as enjoyable learning condition.

To run a better learning process, an enjoyable environment is needed (Bond, 1979). Mingle model is constructed in preparation; initial and preliminary activity in the learning process which proceeds with warming up and setting the rule. Then subsequently employed act mingle, presentation, discussion and ended by concluding the impact on reading skills for dyslexic students.

When playing the game, there should be certain rules set followed by the children to ascertain the flow (Bond, 1979). Teachers need to explain specifically about the rules set including group divisions, how to play, time, gift and tools.

Mingle based learning model is beneficial in teaching reading skills. Teachers get more focused and serious in teaching and it also creates the enjoyable and comfortable environment, as previously stated that to run a better learning process, an enjoyable environment is needed (Bond, 1979). In Thorndike's Law of Exercise, reading proficiency can be best achieved by performing the perpetual exercise of parts of the lesson in correct order. Additionally, this is also supported by the Law of Readiness which asserts that maturity determines individual' readiness to learn. Despite many stimulations given to children, they would not be able 
to learn and show behavior transformation when they are not in the right phase. On the other side, children with dyslexia are suffered from neurology function disorder that caused them to misfit the reading with their perception.

\section{CONCLUSION}

Findings on data analysis showed that mingle model improve elementary reading skills of dyslexic students in primary school despite slight significant results. The improvement in students' reading skills provides positive influence towards students' motivation in completing the tasks and participating in other learning activities.

Based on the research finding showed that mingle model could improve elementary reading skills and enhance the motivation of dyslexic students. this model can be an alternative model for overcoming reading competency of the dyslexic students. In getting the learning result more optimum, the next researcher needs to study deeply.

\section{REFFERENCE}

Anastaha, D. A., Fitria, Y., \& Irdamurni, I. (2018). The effect of inquiry learning toward 5th grade students' understanding on sciences based on motivation in padang. Jurnal Aplikasi IPTEK Indonesia, 2(3).

Bhatnagar, S. C., Mandybur, G.T., Buckingham, H. W., \& Andy, O. J. ( 2000). Language Representation in the human brain: Evidence for Cortical Mapping. Brain \& Language, 74, 238- 259.

Bond, G. L. (1979). Reading Difficulties: Their Diagnosis and Correction, New Jersey: Prentice Hall.

Hurlock, S. (2004). U.S. Patent No. 6,801,883. Washington, DC: U.S. Patent and Trademark Office.

Kirk, S. A., \& Gallagher, J. J. (1962). Education Exceptional Children. Boston : Houghton Mifflin.
Leisman, G. (2002) Coherence of Hemispheric Fungtion in Developmental dysleksia. Brain and Cognition, 48, 425- 431.

Lerner, J. W. (1981), Learning Disabilities : Theories, Diagnosis, and Teaching Strategies, New Jersey: Houghton Mifflin Company.

Lerner, J. W. (1988). Learning Disabilities, New Jersey: Houghton Mifflin.

Lovit, T. C. (1989). Introduction to learning Disabilities. Boston : Allyn and Bacon

Martini, J. (2009). Kesulitan Belajar, Perspektif, Assesmen dan Penanggulangannya. Jakarta: Yayasan Panamas Murni.

Mercer. D. C., \& Mercer, R. A. (1979). Teaching Students With Learning Problems. Columbus: Charles E Merill Book Company.

Pollard, L., \& Hess, N. (1997). Zero prep: Ready-to-go activities for the language classroom. Burlingame, CA: Alta Book Center Publishers.

Scarborough, H. S., Neuman, S., \& Dickinson, D. (2009). Connecting early language and literacy to later reading (dis) abilities: Evidence, theory, and practice. Approaching difficulties in literacy development: Assessment, pedagogy and programmes, 23-38.

Simos, P. G., Breier, J. I., Fletcher, J. M., Foorman, B. R., Bergman, E., Fishbeck, K., \& Papanicolaou, A. C. (2002). Brain activation profiles in dyslexic children during non-word reading: a magnetic source imaging study. Neuroscience letters, 290(1), 61-65.

Walker, J. E., \& Norman, C. A. (2006). The neurophysiology of dyslexia: A selective review with implications for neurofeedback remediation and results of treatment in twelve consecutive patients. Journal of Neurotherapy, 10(1), 45-55.

Watson, C., \& Willows, D. M. (1995). Informationprocessing patterns in specific reading disability. Journal of learning disabilities, 28(4), 216-231.

Yusuf, M., Choiri, S., \& Gunarhadi, G. (2018). The Effectiveness of Inclusive Education and Child Protection Training on Understanding Inclusive Education Subject Matter. Journal of ICSAR, 2(1), 82-87. 